\section{Solid om sosialpsykiatri}

Craig Morgan, Dinesh Bhugra, red. Principles of social psychiatry

2. utg. 602 s, tab, ill. Chichester: Wiley-Blackwell, 2010. Pris GBP 75 ISBN 978-0-470-69713-9

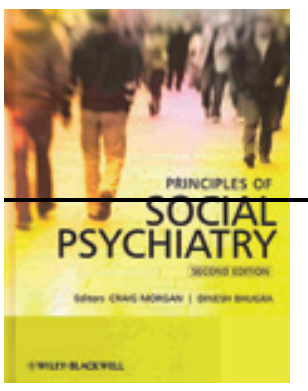

Sosialpsykiatri er et felt som omhandler de effektene som det sosiale miljøet i bred forstand har på den enkeltes mentale helse, og den påvirkningen som individet med mentale helsepro-

blemer har på sitt eget miljø. Feltet står epidemiologien nær, og forfatterne tar utgangspunkt i forekomst og årsaksforhold knyttet til de forskjellige tilstandene, når temaer som definisjon og oppdagelse av klinisk signifikant lidelse, forebyggelse, opplysningskampanjer til befolkningen og forskjellige sosiale intervensjoner blir behandlet. Sosialpsykiatri som felt har berøringspunkter med organiseringen og administrasjonen av kommunehelsetjenesten og dessuten helsetjenesteforskningen. Den raske endringen av de sosiale strukturene som vi i mange samfunn er vitne til i dag, har mange årsaker, hvor transkulturelle aspekter knyttet til massemigrasjon og globalisering er viktige temaer.

Boken er meget omfattende og innholdsrik og dekker de relevante områdene. Den består av seks deler og 43 kapitler med $i$ alt 71 bidragsytere. De fleste av disse kommer fra Storbritannia, særlig London, som er et tradisjonelt tyngdepunkt for sosialpsykiatrien. Ikke alle kapitlene er like opplysende, men flere av dem er svært nyttige oppdateringer på feltet. Forfatterne er klare på at de sosiale faktorene er i interaksjon med genetiske, biologiske og psykologiske komponenter i forståelsen av hvordan mentale lidelser oppstår og utvikler seg, og at disse enkeltkomponentene utgjør et samlet hele og ikke konkurrerende standpunkter. Slik virker fremstillingen balansert og blir også nyttig for klinikeren.

Dette er en lærebok i sosialpsykiatri og ingen vanlig lærebok i klinisk psykiatri. Målgruppen blir derfor mer begrenset. Imidlertid vil de som underviser i psykiatri på høyskole- og universitetsnivå, finne mye stoff av interesse, og jeg anbefaler at boken også er tilgjengelig ved alle institusjoner som utdanner spesialister i psykiatri og klinisk psykologi.

\section{Stein Opjordsmoen Ilner}

Avdeling for forskning og undervisning

Klinikk psykisk helse og avhengighet

Oslo universitetssykehus, Ullevål

\section{Mottaker like viktig som avsender}

David Biro

The language of pain

Finding words, compassion, and relief. 256 s, ill. New York, NY: W.W. Norton, 2010. Pris USD 25 ISBN 978-0-393-07063-7

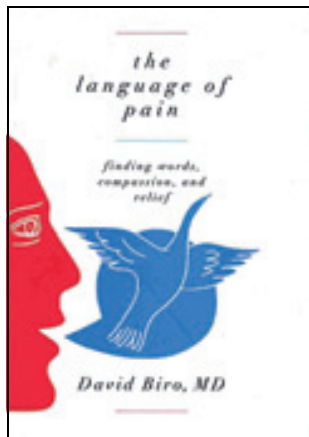

Forfatteren er spesialist $i$ dermatologi og har selv gjennomgått en vellykket beinmargstransplantasjon. Av og til opplevde han perioder med sterke smerter. Som lege som ble pasient, opplevde han sterkt hvordan hjelperne varierte i deres

evne til å oppfatte hvordan han hadde det. Medfølelse og lindring (compassion and relief) er gjennomgangstonen.

I innledningen bruker han Edvard Munchs Skrik og The Faces Pain Scale som illustrasjoner på grader av smerte med følgesymptomer som angst og fortvilelse. Han gir en fargerik beskrivelse av krisen en person opplever, som brått har sterke smerter, og kontrasten til hjelperen på «utsiden», som vanskelig kan begripe nøyaktig hvordan smertepasienten egentlig har det. Biro siterer mange forfattere og filosofer, bl.a. filosofen Ludwig Wittgenstein (1889-1951), og han kommer flere ganger tilbake til det stumme skriket til Munch for å illustrere hvor vanskelig dette er.

Men så finner han frem til det mye brukte McGill smerteskjema, hvor man foreslår mange ord og uttrykk som en person kan velge for å beskrive sin opplevelse av smerte. Han finner også frem til definisjonen av smerte fra The International Association for the Study of Pain: «Smerte er en ubehagelig sensorisk og følelsesmessig opplevelse assosiert med aktuell eller potensiell skade på vev, eller det beskrives som en slik skade.» Forfatteren siterer mange forfattere som beskriver selvopplevd smerte i kraftfulle ord og uttrykk. Han har med kopier av maleriene til Frida Kahlo (1907-54). Hun hadde forferdelige, kroniske smerter etter en trafikkulykke.

Forfatteren har fått frem hvor vanskelig det er for den som lider, å uttrykke dette. Han er mindre opptatt av mottakeren av smertebeskrivelsen. Empati, evnen til å føle med den som lider, er helt nødvendig for at denne kommunikasjonen skal fungere. Evnen til empati er ulikt fordelt, også blant helsearbeidere. Noen har ikke evne til å føle andres lidelser overhodet. Andre lider for mye med pasienten - og sliter seg ut på grunn av det. Helsemedarbeidere, ikke minst legene, må være utstyrt med en riktig balansert evne til empati for å kunne forstå og føle med pasienten i tilstrekkelig grad til å kunne hjelpe. For lite og for mye kan være like galt.

\section{Harald Breivik}

Det medisinske fakultet

Universitetet i Oslo

\section{Obstetriske algoritmer}

Errol R. Norwitz, Michael A. Belfort, George R. Saade et al.

\section{Obstetric clinical algorithms}

Management and evidence. 192 s, tab, ill. Chichester: Wiley-Blackwell, 2010. Pris GBP 35. ISBN 978-1-4051-8111-2

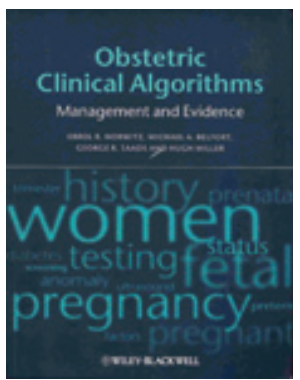

Forfatterne påpeker at det krever ekspertise å finne frem, fortolke og applikere forskningsresultater. Selv innenfor et relativt lite felt som obstetrikk og gynekologi, publiseres det ca. 100

originalarbeider og 35 redaksjonelle kommentarer hver måned, hvilket gjør det vanskelig å være oppdatert på den nyeste viten til enhver tid. Forfatterne argumenterer derfor for at utviklingen av standardiserte medisinske algoritmer og/eller flytdiagrammer kan være et middel for å sikre pasientene kunnskapsbasert behandling.

Boken er bygd opp av «best practise»flytdiagrammer, samtidig med at kunnskapsnivå er lagt inn i diagrammet ved hjelp av fargekoder. Hvert kapittel er systematisk bygd opp med flytdiagrammet på den ene siden og relevant, kortfattet tekst til hver anbefaling i oppslag. Formatet er fint med i alt seks tematiske seksjoner som består av 4-25 omtalte emner, hvilket gjør det enkelt å slå opp.

Seksjonene som omhandler infeksiøse, antenatale, intrapartale og post partum komplikasjoner er naturlig nok de mest omfattende og dekker de fleste problemstillingene innenfor området.

I en del kapitler kommer det tydelig frem at forfatterne er amerikanske. Det gjelder f.eks. i avsnittet om vaginal fødsel etter tidligere keisersnitt. Spørsmålet om hvilke kvinner som kan føde vaginalt etter tidligere keisersnitt, er ikke vurdert i forhold til kunnskapsnivå. Her presiserer man at det må innhentes underskrevet samtykke fra kvinnen hvis hun velger å forsøke vaginal fødsel, og at det må gis informasjon om sannsynligheten for å føde vaginalt samt om risiko for akutt keisersnitt, mens det ikke er en presisering av at kvinnen må 